IIUC STUDIES

ISSN 1813-7733

Vol.- 6, June 2010 (p 53-64)

\title{
Celtic Tradition: The Guiding Force of William Butler Yeats
}

\author{
Sajjadul Karim*
}

\begin{abstract}
The folklore, myth, and legends of ancient Celtic traditions inspired William Butler Yeats a lot. By not falling into the trap of overly romanticizing his work, as many other authors of the time would do, Yeats was able to begin a tradition of another sort, the Irish literary tradition. By giving importance on the Irish culture in his work, Yeats fulfilled his own sense of national pride to the delight of his readers and audiences and to the chagrin of many of his English contemporaries who felt that nothing of value or worthy of study could come out of Ireland. From 1890 he was a member of the occult group of the Golden Dawn', which fuelled his fascination with the mystic symbols of rosicrucianism and cabbalism. Because of these activities his thinking gave an emphasis on magic and apocalypticism that would remain a constant feature of his work. This article aims at exploring the Irish myth, folklore, occultism and the tradition that inspired William Butler Yeats.
\end{abstract}

In the late $1800 \mathrm{~s}$, Yeats came into contact with two very unrelated movements, the Irish nationalists and the Theosophists (an occult/magical sect), and took an active part in both. During all this time of involvement with mystical and nationalist groups, he kept on writing and campaigning for original, autonomous Irish art. Yeats wrote prose, poetry, plays, essays, and parts of an autobiography. Eventually, he became one of Ireland's most prominent writers. Drake says, "Yeats's ambition to create a new Irish poetry - nationalist but with occult perspectives, Celtic but written in English - reflected his need to root himself imaginatively in Ireland, despite the fact that he spent much of his early life in London." (p.12) Yeats was eager to discover his own identity as an Irishman. To accomplish this, he developed his own form of magic through incorporating the Celtic

* Assistant Professor, Department of English Language and Literature, IIUC 
myths of his native land. Maud Gonne, the lady of his desire throughout his life, was fused with his vision, thus creating a sense of a new generation that must be spawned to create the perfect Irish race. Yeats's early poetry is laden with some of the most complex yet classic images in the occult, which were often misunderstood in contemporary times. Yeats's 1899 collection of poems, The Wind Among the Reeds proved to generate "reactions to the volume [that] were quizzical. In some quarters bewilderment was expressed at [Yeats's] deliberate search for obscurity... above all, the new volume's reliance on elaborate magical symbols was worrying" (Foster 217).

One poem that illustrates how Yeats mixes folklore and nationalism is "The Song of Wandering Aengus." In this poem, Yeats refers to Aengus, the Irish god of love. He was said to be a young, handsome god that had four birds flying around his head. These birds symbolized kisses and inspired love in all who heard them sing. In the poem, "The Song of Wandering Aengus", one can clearly see Yeats's fascination with the occult as a way of incorporating classic pagan and Celtic myths as a means of creating an alternative reality for his own nationalistic intentions. Ellmann says, "His occult experiments confirmed his nationalism, and his nationalism, in some way, justified his magical experiments." (p. 289)

Maud Gonne is more than the tangible woman for Yeats. She is a symbol of all that he is trying to attain. Therefore, Gonne is not only the physical woman but also a new Irish race reaching fruition. In this poem, Yeats magically transports the reader into a Celtic collective subconscious where a union between him and Maud Gonne is displayed as the hopeful salvation of the Irish race.

Yeats takes the reader on a journey into the collective subconscious of Celtic pagan mentality where he will conceive of a new version of the Irish self by means of astral projection. Any occult ritual begins with an invocation to the elements along with an announcement of one's intentions. Yeats effectively accomplishes this within the first stanza of "The Song of Wandering Aengus". He mentions "wood", "fire", "moths" and a "stream", thus correlating with earth, fire, wind and water respectively. Now that the elements have been paid their dues, Yeats is ready to move onwards on a more experimental journey. If one takes into account the common images utilized by the occult community then it becomes clear that Yeats's first stanza of "The Song 
of Wandering Aengus" is with bold reference to astral projection. The initial lines of the poem,

I went out to the hazel wood, Because a fire was in my head, And cut and peeled a hazel wand, And hooked a berry to a thread;

Refer both to a magical transgression that is about to take place, as well as a primordial forest with ancient man with his new found tool and key to his existence, fire, blazing him onwards, just as a fever of passion would rage. The reference to "hazel" is of extreme significance. Sacred trees feature in virtually all ancient cultures. The Celtic month of Coll, which consists approximately of August 5th to September 1st, is correlated with the hazel tree. Yeats chooses the hazel tree rather than any other specifically for his purpose of weaving an image of Celtic mysticism.

Yeats proceeds directly into his voyage into the subconscious where he will encounter an image of Maud Gonne, continuing with the second half of the opening stanza,

And when white moths were on the wing,

And moth-like stars were flickering out,

I dropped the berry in a stream

And caught a little silver trout.

The time of day in this scene deserves notice. "Aengus goes fishing in the twilight of dawn when 'white moths' fly and when the 'moth-like stars' flicker out, the time, as Yeats often pointed out, when miracles are most likely to take place" (Unterecker 91). Indeed, this hour above all others is popularly believed to "represent the hour before dawn, the hour of witches and metamorphosis". This was the ideal time for him to "go back to the beginning of Irish culture, the twilight dawn when Ireland was "Eire"" (Flannery 67). Therefore, it is at this stage, that Yeats rips though the fabric of time entirely.

Yeats, now firmly in the realm of the unified subconscious, clearly makes the connection of his union and perspective progeny as a means of reviving a better Celtic Irish race in the second stanza of "The Song of Wandering Aengus".

When I had laid it on the floor I went to blow the fire aflame, 
But something rustled on the floor,

And someone called me by my name:

This scene is primarily about wish fulfillment. The ancient empire of Babylon is a rich source of magic and a source of inspiration for magicians and would-be magicians such as Yeats. A key figure in the Babylonian magical system is Ishtar, the goddess of fertility and love, who was invoked to exorcise evil spirits. The "one" could be Yeats, Aengus, Gonne, the ancient Celtic man with primal fires, the reader, or more than likely the "one" unified consciousness of all of these. This "one" holds magical supremacy, for there is the realization of the power that is within names.

Yeats proceeds in his journey through magical imagery to find the idea of Maud Gonne pervading his thoughts and consciousness. The second stanza concludes with,

It had become a glimmering girl

With apple blossom in her hair

Who called me by my name and ran

And faded through the brightening air.

The "glimmering girl/With apple blossom in her hair" can easily be associated with Gonne, for "one way to read the poem is, of course, to remember that Yeats had first seen Maud Gonne standing beside a bouquet of apple blossoms and that he always identified apple blossoms with her complexion" (Unterecker 91). Truly, Yeats had a lifelong obsession with Gonne, for not only does he try to reach selfactualization by possessing her immortally in prose, but she shared his political ambitions that he felt were key to the proper revival/survival of Ireland.

Yeats realizes that his task is to revive the Celtic tradition in the hearts of the Irish populace. Bloom says, "Aengus is Yeats's god of lovers, in the sense that every man can say: "whenever I am in love it is not I that am in love but Aengus who is always looking for Edaine through somebody's eyes.' The strength of the lyric is that it finds inevitable expression for this universal compulsiveness. It echoes Keats and Morris, and overtly displays what is best in Pre-Raphaelite technique" (p. 126). The subject matter of the poem alone helps illustrate Yeats's profound sense of nationalism. By choosing a Celtic god over the more traditional use of Greek or Roman gods in poetry, the poet attempted to elevate Irish mythology in the world of literature. 
Importantly, in the imagery of The Tower we find a reference to the classic occult symbolism. The image of the tower (which is also commonly referred to as 'The Tower struck by Lightening' or 'The House of God' ) is a symbol that indicates a great need for change through violent destruction. The result of this change is chaos, yet freedom. It is an apocalyptic image, which scholars associate with the fall of the Holy Roman Empire. Here, we can see that Yeats is no longer content to dream his reality, but he is using the symbol of the tower to herald a new time in his life as well as in history.

Many of the early works of Yeats share this common theme of Celtic folklore and myth. As the poet continued in this manner, it becomes clear to the reader that the thematic elements of the work become more focused. The poet moves towards a distinctly Irish sensibility with regard to love of country and this can be seen in his work. In the poem, "To Ireland in the Coming Times" Yeats again draws upon Irish folklore and mythic symbols and sets them against a backdrop of national identity. When Yeats writes,

When Time began to rant and rage

The measure of her flying feet

Made Ireland's heart begin to beat;

He is speaking of the effects of the Industrial Revolution, "When Time began to rant and rage." How the pre-industrial rhythm of life had been interrupted by the hourly wage in the cities, as opposed to the pastoral life of the country that was governed by the changing of the seasons, rather than the movement of the hands of a clock. This accelerated pace of life and of time, "The measure of her flying feet," was reviled by Yeats and he wrote of his distaste for current English life, referring to passions that a man might yet find in Ireland, "love of the Unseen Life and love of country." (Saddlemyer 6). The incompatible pace of modern life in England did not connect with Irish patterns of living and so, "Made Ireland's heart begin to beat", here Yeats is writing of the awakening of an Irish literary tradition. This sentiment is touched upon again further along in the poem, though this time Yeats brings Celtic imagery into it,

Yet he who treads in measured ways

May surely barter gaze for gaze.

Man ever journeys on with them

After the red-rose-bordered hem. 
Ah, faeries, dancing under the moon, A Druid land, a Druid tune!

These lines restate the "measured" way of life in England, its obsession with commerce - "barter gaze for gaze" - and how the English way of life has spread beyond its borders - "Man ever journeys on with them". Yeats then emphasizes Irish imagery; the rose, the faeries and the Druid that are all closely associated with Ireland and are used here to disparage the rigid and structured English world view.

Yeats took inspiration from the myths and legends of ancient Ireland in order to create a conspicuously Irish literature. Cuchulain ${ }^{2}$ as a character appears many times in Yeats's work and it is useful to explore the historic significance of this character. The legend of Cuchulain is a story that predates the arrival of Christianity to the island. Cuchulain is a character that appears in the Ulster Cycle of stories, and he, much like Hercules or Achilles of Greece, and other heroes of myth, was a superhuman warrior figure. Cuchulain is the hero most identified with Ireland and represents both positive and negative aspects of the Irish people and their struggle.

Much later in his career, Yeats would revisit the folkloric themes that were so pervasive in his early work with the poem, "Cuchulain Comforted". In this work Yeats describes the death of the Irish hero, "...He leant upon a tree / As though to meditate on wounds and blood." Here the tree has replaced the pillar stone of the myth. Yeats then writes, "A Shroud that seemed to have authority / Among those birdlike things came, and let fall / A bundle of linen. Shrouds by two and three." The burial garment is appropriate at the scene of a dying man, but a "Shroud that seemed to have authority" seems to be imposing its will upon the fallen hero. If Cuchulain represents Ireland in this poem, then the bearer of the shroud (Morrighan in the legend) or the shroud itself might be indicative of malevolent forces within Ireland that prevent progress and put heroic ideals to death. Too often in Irish history have those that sought an independent free Ireland been undone, not by the English, but by a lack of solidarity from within. Yeats once said of Celtic plays,

"They would be far more effective than lectures and might do more than anything else we can do to make 
the Irish, Scotch, and other Celts recognize their solidarity" (Saddlemyer 77).

This recurrent motif in his work relates to folklore in the sense that folklore is an oral tradition, passed down through generations. Yeats, when speaking of the difference between Irish and English literature had this to say, "Irish poetry and Irish stories were made to be spoken or sung, while English literature has all but completely shaped itself in the printing press" (Thuente 243). When the poet writes, "Though all was done in common as before, / They had changed their throats and had the throats of birds.", this line speaks to the oral tradition of folklore. In the retelling of the same stories over time, certain parts of the story might be altered depending upon the teller, though the overall structure of the story would remain the same. Yeats recognizes this and spoke of Irish legends as, "...ever changing, ever the same" (Thuente 196).

Yeats wrote plays that relied heavily upon the myths and legends of ancient Ireland, Among them, On Baile's Strand, Deirdre and The Death of Cuchulain are noteworthy. Though the author deviates from the source material throughout, the core of the plays remains true to their origins. One reason for Yeats's invoking artistic license with certain scenes is that there are practical limitations with what can be done on stage. Another reason for Yeats's re-imagining of these myths is that it would often serve to enhance the dramatic effect of the story. For example, in the play, Deirdre the queen commits suicide at the end of the play by using a knife that she has secreted away. The myth says, "Deirdre stays with King Conchobar, the man who slew her lover, for an entire year before committing suicide by flinging herself from a moving chariot, shattering her head against a stone" (Mac Cana 96). It is clear why Yeats chose one over the other, for the way Deirdre's death is dramatic in the myth, on stage it would not have played in the same way. What Yeats did preserve, however, are the character's motivations and relationships that drive the narrative forward and create a sense of drama and often, tragedy. Yeats would say of folklore that,

"All folk literature, and all literature that keeps the folk tradition, delights in unbounded and immortal things... All folk literature has indeed a passion whose like is not in modern literature and music and art, 
except where it has come by some straight or crooked way out of ancient times" (Thuente 266).

As early as 1895 , he wrote lyrical, symbolic poems on pagan Irish themes, such as those in The Wanderings of Oisin and Other Poems (1889) and The Rose (1893), in the romantic, melancholy tone he believed characteristic of the ancient Celts. The work of this period has an ethereal quality: the language of a poem such as "The Lake Isle of Innisfree" (1893) is composed in terms of soft nostalgia, each stanza forming one long, languorous sentence:

And I shall have some peace there, for peace comes dropping slow, Dropping from the veils of the morning to where the cricket sings; There midnight's all a glimmer, and noon a purple glow, And evening full of the linnet's wings.

His work amplified his interest in the links between poetry and the occult. In tune with these themes, Yeats also wrote The Celtic Twilight (1893) and The Secret Rose (1897), two collections of short stories on Irish subjects. On a visit to Ireland in 1889 he met the beautiful Irish patriot Maud Gonne, whom he loved unrequitedly for the rest of his life. He also proposed to her daughter, Iseult, in 1917. Maud Gonne inspired much of his early work and drew him into the Irish nationalist movement for independence.

His later writings are generally acknowledged to be his best. They were influenced by Georgie Hyde-Lees, his wife from 1917, who claimed to have a mysterious medium's gift for automatic writing. Partly a product of this spiritualist activity, A Vision (1925) is an elaborate attempt in prose to explain the arcane mythology, symbolism, and philosophy that Yeats used in much of his work. In a series of diagrams, Yeats collaborated with his wife's mysterious "communicators" to describe cyclical patterns of cosmic force called the Gyres.

Yeats's desire to be a voice for what he sees as the coming spiritual revolution became more emphatic throughout the course of his career; his mature works are undergirded by the arcane symbology of $A$ Vision, a symbology given him, he believed, by prophetic spirits. A Vision details the features of Yeats's metaphysical universe in painstaking prose; its abstruse argument links the machinations of a mystical geometry with the sublunary endeavours of humankind. 
However, a more eloquent rendering of the relationship between the occult realms Yeats studied throughout his life and the poetry that they inspired finds expression in the earlier work, Per Amica Silentia Lunae (published in 1917). Here we find potent evidence of the tension between private vision and public expression that animated Yeats's desire to give voice to a spiritual renaissance. Nathan, for example, sees in Per Amica an attempt "to make systematic categories for the natural and supernatural orders of experience and for the relationships between them" and considers it "the best statement up to the publication of $A$ Vision of the ontology that underlay Yeats' dramatic theory and practice" (161). Levine also acknowledges the importance of Yeats's metaphysics, regarding Per Amica as "the visionary centre" of Yeats's art and career, a text designed to elaborate the strategies that "continued to shape dramatic and visionary structure" of the rest of his life's work (p. 3).

In 1886, the Irish orientation in Yeats's poetry was first manifested in "The Stolen Child" with its haunting refrain, "Come away. . for the world's more full of weeping than you can understand". This was the beginning of a major theme that Yeats used repeatedly in his poetry, the idea of fairyland as an escape from the real world to a timeless place, a perfect realm of no feeling or emotion, hence, no pain, and the very human temptation to flee from pain into such an escape. Fairy realms were indeed associated with death, but escape to the immortal realms for Yeats meant not just a physical death, but rather death to the will and the ego. In the poem "The Stolen Child," Yeats conveys his criticism of modern society through the tale of a child who is lured away by fairies back to a natural, ideal world. The poem also becomes an extended metaphor for a return to innocence, which the author believes to disappear as human beings grow into adulthood, towards mundane reality.

In 1892, Yeats wrote a letter to his friend John O'Leary, in which he plainly expressed the significance of the supernatural in his work:

"The mystical life is the centre of all that I do and all that I think and all that I write... It bears the same relation to my work as the philosophy of Godwin held to the work of Shelley ... I have always considered myself a voice of what I believe to be a greater renascence--the revolt of the soul against the intellect-now beginning in the world." (Letters 14) 
Yeats's mystical beliefs, combined with his patriotic ideas, make him a man who represents a continuum in the telling of folklore; a man who is aware of both the poetic and political importance of folklore and convinced of the truth of the stories. If he had not believed in the reality of the fairies, he would have either treated them in an academic way, or as simple poetic stories, but Yeats represents a traditional story-teller who knows about the poetry and truth of his story-- there is no real difference in the attitude of a simple countryman and Yeats's towards the supernatural world. McManus, one of the first to write a natural history of the fairies, reports that his friend Yeats "was fully aware of the 'everyday aspect' of fairy lore and had great respect for it." (p. 12)

Another definition of the fairies3, given by Yeats under the influence of the Theosophists, is also quoted by Ellman: "The fairies are the lesser spiritual moods of the universal mind, wherein every mood is a soul and every thought is a body." (p. 67) So here we find the "little people" not as an expression of the imagination of the people, but as manifestations of the "universal mind," which Yeats had substituted for the God of his grandfather. This kind of pantheism is another expression of Yeats's attempts "to bring together all the fairy tales and folklore he had heard in childhood, the poetry he had read in adolescence, the dreams he had been dreaming all his life." (Ellmann 67)

In his autobiographical sketches, Yeats explains how he gathered some of the stories that later became his collections, or were used as foundations for his own poetical work:

"We had a regular servant, a fisherman ... (My mother) and the fisherman's wife would tell each other stories that Homer might have told, pleased with any moment of sudden intensity and laughing together over any point of satire. There is an essay called Village Ghosts in my Celtic Twilight which is but a report of one such afternoon, and many a fine tale has been lost because it had not occurred to me soon enough to keep notes." (1980: 279)

Yeats is generally regarded as the founder, and certainly as a leading figure, of the Irish Literary Revival, a rediscovery of the old Celtic traditions and forms of art. He "discovered" and supported many writers who became important personalities in the movement, like 
John M. Synge and Lady Gregory. In one of his last poems, "Under Ben Bulben", he reassures his readers of what he had always been trying to tell them: "ancient Ireland knew it all." This includes both his occult ideas and his nationalism. "Under Ben Bulben" is in fact a summary of all of Yeats's philosophy, and well underlines how important, even for our modem age, he considered the old traditions of the ordinary people. The poem ends with his epitaph, confirming its programmatic nature. Indeed, the very name of Yeats has become a synonym for a "collector of folklore." Lysaght says, "most people seem not to be aware that new folklore has been collected since Yeats!” (p. 16)

\section{Notes:}

1. The Golden Dawn - In 1890, Yeats was "excommunicated" from the Theosophists by their leader Madame Blavatsky, because of discrepancies in their beliefs. Yeats, after his "excommunication," did not have to stand alone against a fortress of rationality. On March 7, 1890, months before his expulsion, he had joined the Hermetic Students of the Golden Dawn, another occult sect, which had, among others, the notorious Aleister Crowley among its members. In contrast to the Theosophists, the Golden Dawn put emphasis not on obscure and untraceable Indian and Buddhist masters, but on the European mystical tradition, mainly the Kabbalah. Further contrasting Madame Blavatsky; the Golden Dawn encouraged its members to undertake occult experiments to demonstrate their power over the material universe. That was more to Yeats's taste.

See Colin Wilson: The Occult, London, Grafton Books, 1979.

2. Cuchulain's birth was considered divine in origin and supernatural father figures such as Conall Cernach and Ferghus raised him intermittently as did the King of Ulster, Conchobar. As a youth, he defeats one hundred and fifty of King Conchobar's troops on his way to the royal court. Arriving at the royal court of King Conchobar, the young Cuchulain demands weaponry and then proceeds to break fifteen sets of weapons given to him. Special magically strengthened arms had to be made to withstand Cuchulain's godlike might. His prowess on the field of battle is legendary and is said to have overcome an entire army sent to dispose of him by entering into a supernatural berserk frenzy or 'warp spasm'. When frenzied, Cuchulain cannot make a distinction between friend and foe and some of his allies are victims of his battle madness. 
See Green, Miranda J.: Dictionary of Celtic Myth and Legend. London: Thames and Hudson Ltd, 1992.

3. The 'Old Gods,' the 'Good People' and the 'Fairies' are but a few of the names given to the pre-Christian gods and goddesses of the last Celtic invaders of Ireland. Their folk religion quickly took root and, highly Christianized, proved remarkably resilient in the face of change: for well over a thousand years the 'Old Gods' were universally believed in and their lore considered history.

See Patrick Logan: The Old Gods, Belfast, Apple tree Press, 1981.

\section{$\underline{\text { Works Cited }}$}

Bloom, Harold: Yeats. New York and London: Oxford University Press, 1970.

Drake, Nicholas: Penguin Critical Studies: The Poetry of W.B. Yeats, London, Penguin Group, 1991.

Ellmann, Richard: Yeats -The Man and the Masks, Oxford: Oxford University Press, 1979.

Foster, R. F.: W.B. Yeats: a life, vol. 1 The Apprentice Mage. Oxford, New York: Oxford University Press, 1998.

Flannery, Mary Catherine. Yeats and Magic: The Earlier Works, Gerrards Cross, Buckingshire, Colin Smythe Ltd., 1977.

Levine, Herbert J.: Yeats' Daimonic Renewal, Ann Arbor, UMI Research Press, 1977.

Lysaght, Patricia: The Banshee, Dublin, The Glendale Press, 1986.

Mac Cana, Proinsias: Celtic Mythology, New York, Peter Bedrick Books, 1968.

McManus, D.A.: The Middle Kingdom, London, Max Parrish, 1960.

Nathan, Leonard: The Tragic Drama of William Butler Yeats: Figures In A Dance, New York, Columbia UP, 1965.

Saddlemyer, Ann and Skelton, Robin: The World of W.B. Yeats, Seattle, University of Washington Press, 1965.

Thuente, Mary Helen: W.B. Yeats and Irish Folklore, Dublin, Gill and Macmillan Ltd, 1980.

Unterecker, John: A Reader's Guide to William Butler Yeats, Guildford and London, Billing \& Sons Ltd., 1969.

Yeats, W.B.: Selected Criticism and Prose, London, Pan Books, 1980.

Yeats, William Butler: Letters of W.B. Yeats. Ed. Alan Wade. London: Rupert Hart-Davis, 1954. 